\title{
The Role of Chinese Realia in Mo Yan's Big Breasts and Wide Hips
}

\author{
Ying Sui* and Dong Zhang
}

\begin{abstract}
Philological Faculty, People`s Friendship University of Russia, Moscow, Russia
\end{abstract}
*Corresponding author.Email:suy2019@mail.ru,peterzd@mail.ru

\begin{abstract}
The article is concerned with the role of realia in the novel Big Breasts and Wide Hips by the Chinese contemporary writer Mo Yan and its translation into Russian and English. Based on the material of the literary text, the most representative Chinese realia are collected and studied. The role of Chinese realia in translation into foreign languages is analyzed.
\end{abstract}

Keywords: Realia, National character, National realia, Chinese contemporary literature, Mo Yan, Big Breasts and Wide Hips, Russian translation, English translation.

\section{INTRODUCTION}

Since the formation of the Russian spiritual mission in the 17th and 18th centuries in Beijing, the first Russian sinologists, including Leontiev and Rossokhin, began to translate the classics of Chinese literature [1]. Since then thanks to the efforts of Russian sinologists, a number of well-known works by prominent Chinese writers have been translated into Russian and published in Russia. In particular, these are Lao She's Cat Coutry (1932), Rickshaw Boy (1936), Wang Meng's Movable Parts (1987), Tie Ning's Clumsy Flower (2006), Yu Hua's To Live (2006), Mo Yan's Big Breasts and Wide Hips (1996), The Republic of Wine (2006) and others. The rapidly developing relations between China and Russia over the past decades have given Russian readers the opportunity to get acquainted with the works of the best contemporary Chinese writers. By reading modern Chinese literature Russians can understand China better and comprehend the Chinese mentality. Thus they unwittingly become familiar with many Chinese realia, the existence of which, on the one hand, creates a national-colored flavor and Eastern mystical feelings, while on the other hand, these realia become a significant obstacle to the full understanding of the original text. After the Chinese writer Mo Yan won the Nobel Prize in Literature in 2012, more and more Russian readers pay attention to his works, which was probably also the reason why the Russian translation of his novel Big Breasts and Wide Hips was published so quickly. In this article we attempted to collect the most representative Chinese realia, reveal the meaning of them, and analyze the role that the realia play in Mo Yan's Big Breasts and Wide Hips.

\section{THE CONCEPT OF REALIA}

The term realia is encountered by philologists, translators and linguists, who are dealing with the problems of language, culture and translation. There are no precise criteria for defining this term. In general, realia are represented as a complex material, linguistic, grammatical and lexical concept. Following Tomakhin, we consider realia from two positions:

1) As an object, a concept or a phenomenon characteristic of the history, the culture, the way of life of a particular nation, country and not encountered in other nations;

2) As a word denoting such an object, a concept, a phenomenon, as well as a word-combination (usually phraseology or a proverb) that includes such words [2].

For the time being the realia are also called Wenhua Ciуu or Guosu Ciyu by Chinese researchers.

Realia are included in the words of various cultural categories. Realia indicate a direct or indirect reflection of the national culture. The Bulgarian scholars Vlakhov and Florin argue that realia "are mostly associated with literary works, where they are represented as one of the means of transmitting local and temporary color" [3]. Realia play an important role in the process of creating a 
national character in a literary text. This statement also applies to the novels written by Mo Yan, who uses Chinese realia in comparisons, epithets, and metaphors in his works.

\section{THE ROLE OF CHINESE REALIA IN BIG BREASTS AND WIDE HIPS}

According to literary scholars and translators, the national character of a literary work is often expressed through national realia. The closer the work in its subject matter to the life of the people, the more vividly its national flavor manifests itself. In order to preserve the national flavor of the work, realia, including onomastic realia, when translated into another language, as a rule, are not translated, but transliterated, because they belong to the category of "untranslatable in translation" [2]. The novel Big Breasts and Wide Hips is a "Grand chronicle" of the history of China in the twentieth century. The range of realia in this novel is wide. Despite the fact that all realia are different in origin and their roles in the context of a literary text may not be the same, they are essential elements of the novel, every character of which has a symbolic meaning.

When analyzing the text, we noticed that, first of all, in Big Breasts and Wide Hips Mo Yan used realia to recreate the national characteristics in daily life and to create a special visual, emotional or linguistic appearance;

For example:

(1) Original: "她穿着一件二姐招弟送给她的白绸 旗袍" [4].

Translation in Russian: "На ней был белый шёлковый ципао - подарок Чжаоди" [5].

Translation in English: "She was wearing a white silk hand-me-down cheongsam from Second Sister, Zhaodi" [6].

旗袍 (ципао, the cheongsam or the qipao) - a Manchu women's dress of the usual cut during the Qing dynasty; later, a dress style typically worn by Chinese women. The cheongsam was at the height of its popularity between the late 1920s and 1960s, when it was the standard dress for many Chinese women residing in China's urban cities. The cheongsam as one of the Chinese representative realia was indicated in the works of 梅立崇 (Mei lichong) (1993) [7] and 王国安 (Wang Guoan) (1996) [8].

(2) Original: "德国人修建胶济铁路, 破坏了高密东 北乡的风水" [4].

Translation in Russian: "Немцы проложили железную дорогу из Цзяочжоу в Цзинань, нарушив тем самым дунбэйский фэн-шуй" [5].
Translation in English by the authors: The Germans built a railway from Jiaozhou to Jinan, thus violating Dongbei's Feng Shui.

风水 (фэн-шуй, Feng Shui) - geomancy, determining the most favorable place for a grave or dwelling based on the terrain conditions. The main concept of Feng Shui is in the harmony of people and nature. The Chinese people believe that Feng Shui can influence the prosperity and decline of the family and all subsequent generations [9].

(3) Original: "母亲抱着出生百日的我和八姐去找 马洛亚牧师的时间是这一年的中秋节上午" [4].

Translation in Russian: "На праздник середины осени нам с сестрёнкой как раз исполнилось сто дней. Утром матушка взяла нас на руки и отправилась к пастору Мюррею" [5].

Translation in English: "It was on the morning of the Mid-Autumn Festival, a hundred days after my sister and I were born, when Mother took us to see Pastor Malory" [6].

中秋节 (Чжунцюцзе, праздник середины осени, the mid-Autumn festival) is a traditional Chinese festival, which falls on the fifteenth day of August according to the Chinese calendar. Mooncakes (Yuebing) are usually eaten during the festival [10].

(4) Original: "这样的姑姑, 发誓要把自己的侄女培 养成最模范的淑女, 裹脚自然一丝不苟" [4].

Translation in Russian: "И если такой человек, как тётушка, поклялся, что вырастит из племянницы невесту на загляденье, ноги она, естественно, бинтовала со всем усердием" [5].

Translation in English: "When she promised to raise her niece into a fine young lady, she certainly was not about to cut corners on foot binding" [6].

裹脚 (бинтование ног, foot binding) was the Chinese custom of breaking and tightly binding the feet of young girls. Traditionally, one of the elements of female beauty in old China was considered small feet - "golden lotus". The girls had their feet bound to restrict their normal growth. The process of foot binding was painful and the effects were permanent.

So, intuitively, with the help of representative ethnographic realia, Mo Yan conveys the atmosphere of old China, the beauty and suffering of women.

Then we noticed, that Mo Yan used realia in Big Breasts and Wide Hips to evoke vivid imaginative associations and to achieve the greatest artistic impact.

Mo Yan uses various types of realia in his works to recreate the national character. The story narrated in the novel covers the entire period of the twentieth century, so the readers can learn plenty of the realia at that time: 
(5) Original: "这条铁路就是德国人修建的胶济铁 路" [4].

Translation in Russian: "Здесь и проходила построенная германцами железная дорога Цзяоцзи" [5].

Translation in English: "That rail line was the Jiaoji Line, built by the Germans" [6].

胶济铁路(железная дорога Цзяоцзи, the Jiaoji Line) - the Jiaozhou-Jinan Railway, which was built in 1899-1904, connecting the cities of Qingdao and Jinan in Shandong province. On March 6, 1898, Germany acquired the territory of Jiaozhou Bay and built the Jiaozhou-Jinan railway to expand its influence in China. The background of the novel is based on historical events when Germany invaded the territory of Jiaozhou Bay.

(6) Original: "她爹五月五日被旦本鬼子、不, 皇军, 杀死" [4].

Translation in Russian: "Её отца убили пятого числа пятого месяца японские черти, то бишь императорская армия" [5].

Translation in English: "Her father was killed on the fifth day of the fifth month by the Jap devils — no, I mean the Imperial Army" [6].

Since the second half of the 19th century, the Chinese have referred to foreign invaders from Europe and America as "foreign devils". After the Sino-Japanese war (1894-1895), the names "Japanese devils" or simply "devils" were also used to refer to Japanese aggressors.

There is a description of the military events at that time in Big Breasts and Wide Hips. In particular, the province of Shandong is mentioned, which is rich in natural resources and is well known for its favorable location, as a result of which it frequently suffered from the military actions of major powers.

(7) Original: "袁世凯又派来兵, 活捉了你们祖爷爷 上官斗" [4].

Translation in Russian: "Прислал солдат и Юань Шикай. Они-то и схватили вашего прадеда Шангуань Доу" [5].

Translation in English by the authors: Yuan Shikai sent soldiers again. It was they who grabbed your great-grandfather Shangguan Dou.

袁世凯 (Юань Шикай, Yuan Shikai) (1859-1916) was a prominent military figure, politician, and leader of the Beiyang militarist clique. Here, using one of the realia "Yuan Shikai", the author opens to the readers another layer of Chinese history - the Era of militarists. This period is one of the most important historical events in Mo Yan's novel.
(8) Original: "进财瞪着眼, 鸣鸣噜噜地说: ‘共产 党万岁...... " [4].

Translation in Russian: "А Цзиньцай — глаза выпучены, слова еле выговаривает - «Да здравствует Компартия...»" [5].

Translation in English: "With wide, staring eyes, Jincai stammered, 'Long live the Communist Party...' [6].

共产党 (Компартия, the Communist Party) - the leading and ruling political party of the People's Republic of China, which was founded in 1921.

(9) Original: "进财, 看在咱俩发小的朋友面子上, 我再给你个机会, 你喊一句 “国民党万岁” " [4].

Translation in Russian: "Цзиньцай, вот тебе ещё одна возможность. Крикни «Да здравствует Гоминьдан!»" [5].

Translation in English: "I'll give you one more chance. All you have to do is shout 'Long live the Nationalist Party" [6].

国民党 (Гоминьдан, Kuomintang, the Nationalist Party) - the ruling party during the Republic of China, which was founded in 1894. The real political leaders mentioned by Mo Yan in the novel were directly or indirectly involved in the fate of the characters.

And also we noticed, that Mo Yan used realia in Big Breasts and Wide Hips to depict the characteristic national features of Chinese residents in the twentieth-century.

Since the story was set in the province of Shandong (in Northern China), and the main characters of the novel Shangguan Lu and her daughters - were Northerners in character, a number of specific Northern realia were applied by the writer to describe the national peculiarities and the character of the figures. The expressive imagery of the Shandong dialect - sayings and proverbs contribute to a richer verbal expression of the feelings of the figures. For example:

(10) Original: "她感到, 自己已经走到了阎王爷的 家门口, 催命的小鬼, 抖着哗啦啦响的铁链子, 锁住 了她的脖子" [4].

Translation in Russian: "Она забралась на кан, чувствуя, что уже вошла во врата правителя ада Ло-вана и его служители-демоны, потрясая железными цепями, уже замкнули их у неё на шее" [5].

Translation in English: "She was convinced she'd wandered into the doorway of Yama, the King of Hell, and that his little demons had looped a chain around her neck to drag her inside" [6]. 
The word 小鬼 (служитель-демон, little demon) is used by the author to express the tragic fate of the heroine after she got married.

(11) Original: "怀孕之后，母亲跑到谭家窝棚的娘 娘庙里, 烧香、磕头、许愿..." [4].

Translation in Russian: "Забеременев, Шангуань Лу сбегала к алтарю матушки-чадоподательницы, что стоял в домишке семьи Тань, воскурила благовония, отбила поклоны..." [5].

Translation in English: "Once she was sure she was pregnant, Mother went to the Matron's shrine at the Tan family tent, where she burned incense, kowtowed, made her vows..." [6].

娘娘庙 (алтарь матушки-чадоподательницы, the Matron's shrine) - a kind of temple in China. Most of the people who worship Niang Niang Temple are women, and their main wish is to ask for children.

(12) Original: "大慈大悲、救苦救难的观音菩萨, 保佑我吧，可怜我吧，送给我个男孩吧......" [4].

Translation in Russian: "O Гуаньинь, бесконечно милосердная и сострадающая, помогающая в нужде и вызволяющая в беде, оборони и смилуйся, пошли мне сына..." [5].

Translation in English: "Merciful Bodhisattva Guanyin, who succors the downtrodden and the distressed, protect and take pity on me, deliver a son to this family..." [6].

观音菩萨 (Гуаньинь, Bodhisattva Guanyin) - the Buddhist bodhisattva associated with compassion. The Chinese traditional patriarchy brings the heroine severe mental suffering.

(13) Original: "真真是 “毒不过黄蜂针, 狠不过郎中 心' " [4].

Translation in Russian: "Вот уж правду говорят: «Нет ничего ядовитее осиного яда и безжалостнее сердца лекаря»" [5].

Translation in English: "There is nothing more poisonous than a hornet's sting and nothing more ruthless than a physician's heart" [6].

Original: "五姐夫,俗话说: “秤秆不离秤砣, 老汉不 离老婆, " [4].

Translation in Russian: "Пятый зять, как говорится, грузик при безмене, а жена при муже." [5].

Translation in English: "Fifth Brother-in-law, there's a popular saying that a steelyard's sliding weight doesn't leave its arm, and a good man doesn't leave his wife" [6].

Proverbs are beautiful in form, concise and expressive. They increase the vividness of the language and bring the readers associations with Chinese Northern culture.
(14) Original: "这就对了。三，别听司马家大疯子 胡吣，日本人来干啥?”[4].

Translation in Russian: "И не слушай ты, Сань, россказни этого полоумного Сыма! Ну зачем японцы сюда потащатся?" [5].

Translation in English: "That's right, why listen to the ravings of that crazy Sima? What would the Japanese want with a backwater village like ours?" [6].

The word 吣 means "vomit", which in the figurative sense of the local dialect can be translated as "stupidity" and "talking nonsense". Dialect allows the readers to enjoy the richness of the language. Dialect help the readers understand the writer's intentions better and discover the characteristics of the figures deeper.

\section{CONCLUSION}

P. Skosyrev noted that national character begins with the character of the author [11]. This statement may also apply to Mo Yan's works. Analysis of examples showed that Mo Yan endued Big Breasts and Wide Hips with several sorts of realia to present the Chinese national character. In literary works realia are able to recreate national characteristics in daily life, to create a national-historical background of the story and to depict the characteristic national features of Chinese residents in the twentieth-century.

Mo Yan is adept at paying attention to tiny details, with which he creates the national-historical background of the work, which is of great importance for foreign readers since it is these culturally marked units that convey information about the way of life of an individual nation.

\section{REFERENCES}

[1] History of the Russian Spiritual mission in China: a collection of articles. M., 1997. 415 p

[2] Tomakhin G. D. Realii-americanizmy. M.: Higher school, 1988. $239 \mathrm{p}$

[3] Vlakhov S., Florin S. Untranslatable in translation. Moscow: International relations, 1980. 343 p.

[4] Mo Yan. Big Breasts and Wide Hips. // - Beijing, The Contemporary World Press, 2004. - 604 p.

[5] Mo Yan. Big Breasts and Wide Hips. / TRANS Egorov E. A. Saint Petersburg, Amfora publishing House, 2013, 518 p.

[6] Mo Yan. Big Breasts and Wide Hips: a Novel, translated from the Chinese by Howard Goldblatt. New York: Arcade. 2004. 
[7] Mei Lichong. Incompetent judgment of words of national tradition. [J]. // - Beijing, Chinese Teaching in the World, 1993 (1), 33-38 pp.

[8] Wang Guoan. Analysis of cultural words and cultural semantics of the Chinese language [A]. Selected Papers of the Fifth Symposium of China Association of Teaching Chinese as a Second Language // - Beijing, Beijing Language and Culture University Press, 1996. 495 p.
[9] Zhao Ming. Modern Chinese Cultural Words. // Beijing, China Social Sciences Press, 2016. 474 p.

[10] Zhang Gaoxiang. "Cultural words in teaching Chinese as a foreign language". // - Kunming, Bulletin of Yunan Pedagogical University, 2016, 61-65 pp.

[11] Skosyrev P. Inheritance and search: articles, essays, notes. / P. Skosyrev, 1961. 295 p. 